\title{
Accounting And Cultural Values: IFRS In 3G Economies
}

David R. Borker, Manhattanville College, USA

\begin{abstract}
The $3 G$ countries represent the most recent attempt to identify a set of world economies that will exhibit the greatest growth by the middle of this century (Buiter and Rahbari, 2011). They are classified by a Global Growth Generator, or $3 G$ index, based on six specific growth drivers. Of the eleven $3 G$ countries identified, India and China have received the most significant attention previously, as members of the so-called BRIC countries. The remaining countries consist of Bangladesh, Egypt, Indonesia, Iraq, Mongolia, Nigeria, Philippines, Sri Lanka, and Vietnam.

This paper aims to shed light on the cultural/business mindset of managers in these countries, using survey data and concepts of two internationally oriented scholars, Geert Hofstede (1988) and S. J. Gray (1980). Their combined work has provided a robust framework for studies of the potential impact of cultural values on management and accounting. In a previous paper, we examined the cultural characteristics of each $3 G$ based on the Hofstede six cultural dimensions to determine the unique and shared value characteristics of the $3 G s$ that may affect economic growth. (Borker, 2013a) Here, an accounting profile is developed for each $3 G$ based on cultural accounting values derived by Gray from Hofstede's dimensions. Profiles are created and compared to one another, and to a proposed independent IFRS favorable profile (Borker, 2013b), as part of an analysis of cultural and other factors that may affect the long-term success of IFRS in the 3Gs. The impact of these profiles on several growth factors is also discussed.
\end{abstract}

Keywords: IFRS; Global Growth Generators; Emerging Economies; Accounting; Culture; Hofstede; Gray

\section{INTRODUCTION}

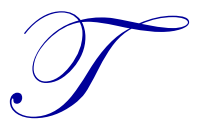

he eleven 3G - or Global Growth Generator countries, identified by Buiter and Rahbari for Citigroup, represent the most recent attempt to construct a list of developing or transitional countries with the best economic growth prospects over the next several decades (Buiter \& Rahbari, 2011). They replace the BRIC group, identified by Goldman Sachs CEO, Jim O'Neill, as consisting of Brazil, Russia, India, and China (O'Neill, 2001). In place of the BRIC, or BRICS since South Africa was added to that list, the Citigroup analysts identify eleven countries that have the highest scores on their 3G Index. Index values are determined by the authors as the weighted average of six specific growth drivers: (1) domestic saving/investment, (2) demographic prospects, (3) health, (4) education, (5) quality of institutions/policies, and (6) trade openness. Some of these factors are relatively simple. Domestic Savings/Investment is a straight forward statistic. Also, health is measured primarily in terms of having a relatively low ranking for infant mortality rate. Demographic prospects' focus is on high birthrates and high projected growth of the working age population relative to other groups. Other factors, like education, the quality of institutions and policies, and trade openness are more complex and more subjective in nature.

The 3G countries are listed in Table 1 in order of the rank from highest to lowest on the Global Growth Generator Index. For example, Vietnam has highest ranking with a 3G Index score of 0.86 and Nigeria has the lowest ranking with a $3 \mathrm{G}$ Index score of 0.25 . 
Table 1: Global Growth Generators (3G) countries 2010-2050

\begin{tabular}{|l|c|}
\hline \multicolumn{1}{|c|}{ Country } & 3G Index \\
\hline Viet Nam & 0.86 \\
\hline China & 0.81 \\
\hline India & 0.71 \\
\hline Indonesia & 0.70 \\
\hline Mongolia & 0.63 \\
\hline Philippines & 0.60 \\
\hline Iraq & 0.58 \\
\hline Bangladesh & 0.39 \\
\hline Egypt & 0.37 \\
\hline Sri Lanka & 0.33 \\
\hline Nigeria & 0.25 \\
\hline
\end{tabular}

The 3G Index values use a weighted average of the Buiter and Rahbari six growth drivers. The 3Gs include India and China that were part of the BRIC group, plus nine others. All could be described as emerging economies. Some of them, specifically China, Vietnam and Mongolia, can further be described as politically transitional economies moving from the constraints of a command economy under communism to market-driven economies with allocation of financing through securities markets. Most of the others can be viewed as transitioning toward democracy. India is the only relatively stable democracy.

In a previous study (Borker, 2013a), each of the $3 \mathrm{Gs}$ were examined in terms of cultural value characteristics based on the cultural value dimensions developed by Hofstede and his associates (Hofstede, 1980; Hofstede, et al., 2010) to identify cultural grouping or profiles among these countries that might supplement the Buiter and Rahbari economic growth factors as a means of differentiating and ranking the potential growth prospects on a cultural rather than econometric basis. It identified two cultural profile groups and a few outlier countries based on the distribution of the Hofstede six cultural value dimensions. The first cultural profile grouping consisted of Vietnam, China, India and Indonesia - four 3G countries with the highest econometric rankings on the $3 \mathrm{G}$ Index. The second profile consisted of countries with the next highest scores - Philippines, Iraq, Bangladesh, and Egypt. Sri Lanka and Nigeria did not fit any profile and had the lowest 3G Index scores. Mongolia was excluded due to data issues. The study demonstrated the relevance of cultural values to the evaluation of the growth prospects of these countries, as well as, the correspondence between cultural factors and economic factors in the potential growth ranking of the countries.

An important area of cultural values that has not yet been investigated for the $3 \mathrm{Gs}$ is the potential role of culturally derived national accounting values on the quality of financial reporting. The current world standard for high quality financial reporting is International Financial Reporting Standards (IFRS). Successful long-term implementation of IFRS, through adoption or convergence with local accounting standards by national accounting standard setting bodies, has become a political and economic necessity throughout the world. For the 3Gs, in particular, the long-term success of IFRS reporting by their companies is essential to support their projected high growth. All of the 3Gs listed have public stock exchanges including Mongolia, which has the youngest but fasting growing stock exchange in the world, and all are assumed to benefit from the establishment of strong stable standard setting in accordance with IFRS. Reliable IFRS-based reporting assures the fair allocation of capital to each of these countries and also supports a higher level of accountability from a corporate governance standpoint, as well as, from government and professional institutions involved in standard setting.

The goal of this paper is to assess the effect that the specific cultural attributes of individual 3 Gs may have in their long-term success implementing IFRS. The means chosen to achieve this goal is to examine the cultural dimensional indices attributed to each of these countries using the six cultural value dimensions developed by Hofstede (1980) and Hofstede, Hofstede, \& Minkov (2010), and the derived accounting culture value dimensions constructed by S. J. Gray (1988). This information provides useful information about cultural values and attitudes of the individual $3 \mathrm{G}$ countries that enable them to provide financial reporting that will support the efficient allocation of global and domestic investor capital and safeguard investors. 
Compliance with IFRS ranges from complete compliance in China, to the absence of any official declaration on IFRS in Vietnam. Although governments and local accounting standards setting bodies may be at various stages in the harmonization process, there are individual companies reporting in compliance with IFRS in all of the $3 \mathrm{Gs}$. Table 2 provides a brief status for each of the $3 \mathrm{Gs}$ in terms of IFRS adoption/convergence.

Table 2: Summary of IFRS Adoption Status for 3Gs

\begin{tabular}{|c|c|}
\hline 3G Country & $\begin{aligned} \text { Summary Status of IFRS Adoption } \\
\end{aligned}$ \\
\hline Bangladesh & $\begin{array}{l}\text { Current Status: IFRS implementation is incomplete but process continues. IFRS currently not permitted in } \\
\text { full. } \\
\text { IAS standards were first initiated in } 1999 \text {. By } 2005 \text { all domestic listed companies were required to use IFRS. In } 2009 \text {, } \\
8 \text { IFRSs and } 26 \text { IASs had been adopted. This adoption process was to be ongoing until June } 2010 \text {. However, full } \\
\text { implementation is incomplete. }\end{array}$ \\
\hline China & $\begin{array}{l}\text { Current Status: All companies in China are required to follow IFRS and convergence is complete. Chinese } \\
\text { CAS financial statements are accepted by EU exchanges. } \\
\text { IFRS adoption was completed in three phases. In 2006, reporting using new China Accounting Standards (CAS) } \\
\text { consistent with IFRS generally was required for all listed companies. All state owned enterprises were required to } \\
\text { report CAS in 2008. In 2009, all large and medium sized companies were required to use IFRS. }\end{array}$ \\
\hline Egypt & $\begin{array}{l}\text { Current Status: Currently all listed companies are required to use IFRS. } \\
\text { Prior to 1992, all listed companies followed International Accounting Standards (IAS). In 1992, with the passage of } \\
\text { Capital Market Law 95, all listed companies were required to report using Egyptian Accounting Standards (EAS), an } \\
\text { Arabic version of IAS with minor differences. Ministerial Decree } 503 \text { in } 1997 \text { made EAS mandatory for all } \\
\text { companies regulated by the Capital Market Authority. EAS reporting is required by all banks governed by the } \\
\text { Central Bank of Egypt. New EAS rules were issued in 2006. Currently all listed companies are required to use IFRS. }\end{array}$ \\
\hline India & $\begin{array}{l}\text { Current Status: Currently there is partial compliance with IFRS but a delay in full convergence of IFRS with } \\
\text { India GAAP. Only consolidated financial statements of listed companies can use IFRS. } \\
\text { India has complied partially with IFRS since } 2010 \text {, and was expected to reach full compliance at the end of } 2011 \text { but } \\
\text { was delayed by recommendation of the National Advisory Committee on Accounting Standards. Now a three phase } \\
\text { convergence with IFRS is to start on April } 2011 \text {. All three phases depend on the net worth of a company and other } \\
\text { factors such as listings on exchanges outside India. Larger listed companies will proceed first (April 2011). Phase II } \\
\text { and Phases II will be implemented April } 2013 \text { and } 2014 \text { respectively. Currently listed companies are permitted to use } \\
\text { IFRS. }\end{array}$ \\
\hline Indonesia & $\begin{array}{l}\text { Current Status: In 2011, 95\% of IFRS have been adopted in Indonesia. Work is progressing on schedule for } \\
\text { full convergence by } 2012 \text {. However, use of IFRS by domestic listed companies was not yet permitted in 2012. } \\
\text { Initially the Indonesian reporting standards board expected to be consistent with IFRS by } 2008 \text {. This goal was not } \\
\text { reached in } 2008 \text { or } 2009 \text {, but by } 2010 \text {, local standards (PSAC) had made considerable progress. The delays were } \\
\text { mostly due to the need to translate IFRS into the Indonesian language. The new plan was to be fully converged with } \\
\text { IFRS by } 2012 \text {. }\end{array}$ \\
\hline Iraq & $\begin{array}{l}\text { Current Status: Iraq is fully compliant with adoption of IFRS for all domestically listed companies. } \\
\text { Iraq Interim Law on Securities Markets adopted } 2004 \text { says all companies listed on the Iraq Stock Exchange must use } \\
\text { IFRS. Also, banking law administered by the Central Bank of Iraq requires IFRS. }\end{array}$ \\
\hline Mongolia & $\begin{array}{l}\text { Current Status: Exclusive use of IFRS was declared in Mongolia in 1993. Progress has been made with } \\
\text { assistance of the World Bank. } \\
\text { Accounting Law of Mongolia of } 1993 \text { declared that all business entities, both for-profit and not-for-profit, medium } \\
\text { and small, free and state owned enterprises will use IFRS. }\end{array}$ \\
\hline Nigeria & $\begin{array}{l}\text { Current Status: Nigeria began adoption of IFRS in January } 2012 \text { for significant publically listed companies. } \\
\text { Other public companies have an IFRS adoption deadline of January } 2013 \text { and SMEs a deadline of January } \\
\text { 2014. } \\
\text { Statement of Accounting Standards was required since } 1990 \text { and coexisted with IFRS until } 2010 \text { when the } \\
\text { government announced that public listed entities would be required to converge with IFRS with deadlines of } 2012 \text {, } \\
2013 \text {, and } 2014 \text { depending on a classification of company type. From 2012, use of IFRS by domestic listed } \\
\text { companies is permitted. }\end{array}$ \\
\hline Philippines & $\begin{array}{l}\text { Current Status: IFRS was initially required adoption in } 2005 \text { for all companies that filed Philippine GAAP. } \\
\text { Currently, however non-publically accountable entities have the option to report using prior standards. } \\
\text { In 2005, the Accounting Standards Council (ASC) decided to adopt IAS standards. In } 2005 \text { the ASC completed } \\
\text { adoption of IFRS and made it applicable to all reporting entities. However, non-public entities were subsequently } \\
\text { given an option to opt out of IFRS reporting. Most IFRS have been adopted, but some significant modifications were } \\
\text { made. }\end{array}$ \\
\hline Sri Lanka & $\begin{array}{l}\text { Current Status: Sri Lanka Accounting Standards were declared to be fully compliant since 2011. Convergence } \\
\text { is still in progress. Listed companies are permitted to use IFRS. } \\
\text { Prior to 2007, Sri Lanka reported according to Sri Lanka Accounting Standards which had gaps with international } \\
\text { standards. In 2007, the South Asian Federation of Accountants approved bringing local standards compliant with } \\
\text { IFRS. Since 2011, IFRS reporting is permitted. }\end{array}$ \\
\hline
\end{tabular}




\begin{tabular}{|l|l|}
\hline \multirow{3}{*}{ Viet Nam } & $\begin{array}{l}\text { Current Status: Vietnam operates on the Vietnamese Accounting Standards (VAS) and some companies are } \\
\text { making efforts to adopt IFRS, but listed domestic companies are not permitted to use IFRS. } \\
\text { Prior to 1997, Vietnam used a French influenced accounting system. In 1997, a Vietnamese accounting system was } \\
\text { introduced (VAS). Some companies report in the VAS system and IFRS, but there is no government declaration for } \\
\text { universal use of IFRS in Vietnam. }\end{array}$ \\
\hline
\end{tabular}

NOTE: The statuses are based on information provided by several IFRS tracking groups (Deloitte, 2012; PWC, 2012).

There is no literature specifically addressing IFRS in the 3Gs. There does exist some previous research literature on accounting and IFRS harmonization within individual countries that are part of the 3G group. References for studies of financial reporting and IFRS harmonization in individual 3Gs are in Table 3.

Table 3: Previous Selected Research on IFRS Adoption by 3G

\begin{tabular}{|l|l|}
\hline \multicolumn{1}{|c|}{ Country } & \multicolumn{1}{|c|}{ Selected References } \\
\hline Bangladesh & $\begin{array}{l}\text { (Mir \& Rahaman, 2005) (Shil, et al., 2009) (The Institute of Chartered Accountants of Bangladesh, 2007) } \\
\text { (Shil, 2009) (The Institute of Chartered Accountants of Bangladesh, 2009) (UNCTAD, 2006) }\end{array}$ \\
\hline China & (2006) (McGregor, 2006) (Financial Standards Foundation, 2008) \\
\hline Egypt & (World Bank, 2002) (UNCTAD Secretariat, 2008) (Elbannan, 2010) (Kholeif, 2008) (Farag, 2009) \\
\hline India & $\begin{array}{l}\text { (Khatri \& Master, 2009) (Khatri, 2011) (The Institute of Chartered Accountants of India, 2010) (The Institute } \\
\text { of Chartered Accountants of India, 2011) (Venus \& Sales-Suez, 2011) }\end{array}$ \\
\hline Indonesia & $\begin{array}{l}\text { (World Bank, 2005) (ASEAN Federation of Accountants, 2009) (The Indonesia Institute of Accountants, } \\
\text { 2009). (Idonesian Accounting Board, 2011) (World Bank, 2010) }\end{array}$ \\
\hline Iraq & (Deloitte, 2008) (Deloitte, 2012) \\
\hline Mongolia & (ROSC, 2008) (Tomor-Ochir, 2010) \\
\hline Nigeria & (The Institute of Chartered Accountants of Nigeria, 2009) (World Bank, 2011) (Terzungwe, 2012) \\
\hline Philippines & (World Bank Group, 2006) (The Accountant, 2010) \\
\hline Sri Lanka & (eStandardsForum, 2008) (World Bank, 2004) (U.S. Department of State, 2008) \\
\hline Vietnam & (Sarikas, et al., 2009) (World Bank, 2006) \\
\hline
\end{tabular}

The remainder of the paper is organized as follows: Section II examines the six Hofstede cultural value dimensions and the four Gray accounting value dimensions. Section III reports and analyzes the results of applying the Hofstede and Gray dimensions to the 3Gs. Section IV provides a discussion the implications of the accounting profiles of the $3 \mathrm{Gs}$ for successful long-term establishment of IFRS in these countries. Finally, Section V serves as the conclusion.

\section{CULTURE AND ACCOUNTING: AN EXAMINATION OF HOFSTEDE AND GRAY DIMENSIONS}

Research on the topic of culture and its relationship to business and accounting has existed since the 1980 s. In 1980, Geert Hofstede published his Culture's Consequences: International Differences in Work Related Values, based on data from individual questionnaires distributed to IBM managers and employees in 72 countries (Hofstede, 1980). Subsequently, Gray offered a hypothetical set of relationships between the Hofstede dimensions and his own culturally derived accounting value dimensions eight years later (Gray, 1988). Both the Hofstede original four dimensions and his subsequent work, including two more dimensions (Hodstede \& Bond, 1988); (Hofstede, 2001); Hofstede \& Minkov, 2010), have been the subject of much research and debate (Sondergaard, 1994); (Hofstede, 1994); (Spector, 2001); (Baskerville, 2003); (Hofstede, et al., 2010); (Huang, 2007) Similarly, Gray’s application of the Hofstede dimensional indices has led to extensive discussion, testing and application (Perera, 1989); (Gray \& Vint, 1995); (Salter \& Niswander, 1995); (Baydoun \& Willet, 1995); (Emenyonu \& Gray, 1992); (Zarzeski, 1996); (Chanchani \& MacGregor, 1999); (Hope, 2003); (Doupnik \& Tsakumis, 2004); (Chanchani \& Willet, 2004); (Finch, 2009); (Buys \& Schutte, 2011); (Borker, 2013b).

Gray's association of accounting values, based on relationships to the Hofstede cultural dimensions (Hofstede, 1980), is founded on the premise that culture influences accounting. This stems from the general notion that societal values lead to the development and maintenance of institutions within a society, including educational, social, and political systems, and legal, financial, and corporate structures. Once in place, these systems reflect and reinforce societal values, and tend to be stable and remain in place, except where changes are caused by major external factors, such as international trade, investment, multinational companies, and colonization. (Gray, 1988) 


\section{Hofstede Cultural Dimensions}

In his early research, (Hofstede, 1980) identified four measurable cultural dimensions that differentiate cultures. The data upon which these dimensions were initially developed came from pencil and paper survey results collected within one large multinational business organization, although subsequent surveys had a more diverse base. Four dimensions were identified originally, to which two additional dimensions were added subsequently by Hofstede and his associates. All six Hofstede cultural value dimensions are summarized in Table 4, beginning with the original four dimensions (Hofstede, 1980) (Hofstede, 2001) (Hofstede, et al., 2010).

Table 4: Summary of Hofstede's Six Cultural Value Dimensions

\begin{tabular}{|c|c|}
\hline Dimension & Description \\
\hline $\begin{array}{l}\text { Individualism versus } \\
\text { Collectivism (IDV) }\end{array}$ & $\begin{array}{l}\text { The fundamental issue addressed by this dimension is the degree of interdependence that a society } \\
\text { maintains among its members. It has to do with whether people's self-image is defined in terms of "I" } \\
\text { or "We". In individualist societies, people are supposed to only look after themselves and their direct } \\
\text { family. In collectivist societies, people belong to "in groups' that care for them in exchange for loyalty. }\end{array}$ \\
\hline Power Distance (PDI) & $\begin{array}{l}\text { This dimension deals with the fact that all individuals in societies are not equal. It expresses the } \\
\text { attitude of the culture toward these inequalities among us. Power distance is defined as the extent to } \\
\text { which the less powerful members of institutions and organizations within a country expect and accept } \\
\text { that power is distributed unequally. }\end{array}$ \\
\hline $\begin{array}{l}\text { Masculinity versus } \\
\text { Femininity (MAS) }\end{array}$ & $\begin{array}{l}\text { A high score (masculine) on this dimension indicates that the society is driven by competition, } \\
\text { achievement and success, with success being defined by the winner/best in field - a value system that } \\
\text { starts in school and continues throughout organizational behavior. A low score (feminine) on this } \\
\text { dimension means that the dominant values in society are caring for others and quality of life. A } \\
\text { feminine society is one in which quality of life is the sign of success. Standing out from the crowd is } \\
\text { not admirable. The fundamental issue here is what motivates people; i.e., wanting to be the best } \\
\text { (masculine) or liking what you do (feminine). }\end{array}$ \\
\hline Uncertainty Avoidance (UAI) & $\begin{array}{l}\text { This dimension deals with the way a society considers the fact that the future can never be known, i.e., } \\
\text { should we try to control the future or just let it happen? This ambiguity brings anxiety with it and } \\
\text { different cultures have learned to deal with this anxiety in different ways. The extent to which the } \\
\text { members of a culture feel threatened by ambiguous or unknown situations and have created beliefs and } \\
\text { institutions that try to avoid these is reflected in the UAI score. }\end{array}$ \\
\hline $\begin{array}{l}\text { Long-term versus Short-term } \\
\text { Orientation (LTO) }\end{array}$ & $\begin{array}{l}\text { The long-term orientation dimension is closely related to the teachings of Confucius and can be } \\
\text { interpreted as dealing with society's search for virtue; i.e., the extent to which a society shows a } \\
\text { pragmatic future-oriented perspective rather than a conventional historical short-term point of view. }\end{array}$ \\
\hline $\begin{array}{l}\text { Indulgence versus Restraint } \\
\text { (IVR) }\end{array}$ & $\begin{array}{l}\text { The indulgence versus restraint dimension consists of two poles. Indulgence stands for a tendency to } \\
\text { allow relatively free gratification of basic and natural human desires related to enjoying life and having } \\
\text { fun, and the opposite pole. Restraint reflects a conviction that such gratification needs to be curbed and } \\
\text { regulated by strict norms. }\end{array}$ \\
\hline
\end{tabular}

\section{Gray Accounting Value Dimensions}

Extending the concepts of Hofstede's original four dimensions to accounting, Gray suggests that accounting values are derived from such cultural dimensions and, in turn, influence accounting systems. Gray identifies four key accounting values or dimensions. (Gray, 1988) These four accounting dimensions are summarized in Table 5.

Table 5: Gray's Four Accounting Value Dimensions

\begin{tabular}{|l|l|}
\hline \multicolumn{1}{|c|}{ Dimension } & \multicolumn{1}{c|}{ Description } \\
\hline $\begin{array}{l}\text { Professionalism versus } \\
\text { Statutory Control }\end{array}$ & $\begin{array}{l}\text { Refers to professional judgment and self-regulation in contrast to compliance with rigid legal } \\
\text { requirements and legislative control. }\end{array}$ \\
\hline $\begin{array}{l}\text { Uniformity versus } \\
\text { Flexibility }\end{array}$ & Refers to the level of enforcement of standardized and consistent accounting practices. \\
\hline $\begin{array}{l}\text { Conservatism versus } \\
\text { Optimism }\end{array}$ & $\begin{array}{l}\text { Refers to a vigilant approach to accounting measurement, as opposed to a more optimistic and risk- } \\
\text { taking approach. }\end{array}$ \\
\hline $\begin{array}{l}\text { Secrecy versus } \\
\text { Transparency }\end{array}$ & $\begin{array}{l}\text { Refers to confidentiality and the constraint of disclosure of information, as opposed to a more } \\
\text { transparent and publicly accountable approach. }\end{array}$ \\
\hline
\end{tabular}

Gray offered four hypotheses to explicate the relationship between his own culturally based accounting dimensions and Hofstede's original four cultural value dimensions. These hypotheses are summarized in Table 6. 
Table 6: Summary of Gray's Hypotheses

\begin{tabular}{|l|l|}
\hline Hypothesis I & $\begin{array}{l}\text { The higher a ranking in terms of individualism and the lower the ranking in terms of uncertainty avoidance } \\
\text { and power distance, the more likely the country is to rank highly in terms of professionalism. }\end{array}$ \\
\hline Hypothesis II & $\begin{array}{l}\text { The higher a ranking in terms of uncertainty avoidance and power distance and the lower the ranking in terms } \\
\text { of individualism, the more likely it is to rank highly in terms of uniformity. }\end{array}$ \\
\hline Hypothesis III & $\begin{array}{l}\text { The higher a ranking in terms of uncertainty avoidance and the lower the ranking in terms of individualism } \\
\text { and masculinity, the more likely it is to rank highly in terms of conservatism. }\end{array}$ \\
\hline Hypothesis IV & $\begin{array}{l}\text { The higher a ranking in terms of uncertainty avoidance and power distance and the lower the ranking in terms } \\
\text { of individualism and masculinity, the more likely it is to rank highly in terms of secrecy. }\end{array}$ \\
\hline
\end{tabular}

Baydoun and Willet summarized the relationships between each of the Hofstede cultural dimensions and Gray's accounting dimensions by using a plus sign $(+)$ to indicate a "direct relationship" and a minus sign (-) to indicate an "inverse relationship." (Baydoun \& Willet, 1995) A question mark (?) was used to indicate that the nature of the relationship is indeterminate. These direct and inverse relationships between the Gray hypotheses and the Hofstede dimensions are summarized in Table 7 (Borker, 2013b).

Table 7: Direct \& Inverse Relationships between Gray's Accounting Dimensions \& Hofstede's Cultural Dimensions

\begin{tabular}{|l|c|c|c|c|}
\hline & $\begin{array}{c}\text { Power Distance } \\
\text { PDI }\end{array}$ & $\begin{array}{c}\text { Individualism } \\
\text { IDV }\end{array}$ & $\begin{array}{c}\text { Masculinity } \\
\text { MAS }\end{array}$ & $\begin{array}{c}\text { Uncertainty Avoidance } \\
\text { UAI }\end{array}$ \\
\hline Conservatism & + & - & - & ++ \\
\hline Uniformity & + & -- & $?$ & ++ \\
\hline Professionalism & - & ++ & $?$ & -- \\
\hline Secrecy & ++ & -- & - & ++ \\
\hline
\end{tabular}

The relationship between Gray accounting value dimensions and Hofstede cultural dimensions was expanded by Borker to include links to Hofstede fifth and six dimensions, based on an examination of Hofstede value indices for the United States, the United Kingdom, Australia, Canada, and New Zealand (Borker, 2013b). Table 8 combines linkages of Gray dimensions to the Hofstede values of Long-term Orientation (LTO) and Indulgence versus Restraint (IVR) with linkages to the original four Hofstede dimensions illustrated in Table 7.

Table 8: Expansion of Hofstede-Gray Relationships (Borker, 2013b)

\begin{tabular}{|l|c|c|c|c|c|c|}
\hline & $\begin{array}{c}\text { Power } \\
\text { Distance } \\
\text { PDI }\end{array}$ & $\begin{array}{c}\text { Individualism } \\
\text { IDV }\end{array}$ & $\begin{array}{c}\text { Masculinity } \\
\text { MAS }\end{array}$ & $\begin{array}{c}\text { Uncertainty } \\
\text { Avoidance } \\
\text { UAI }\end{array}$ & $\begin{array}{c}\text { Long-Term } \\
\text { Orientation } \\
\text { LTO }\end{array}$ & $\begin{array}{c}\text { Indulgence vs. } \\
\text { Restraint } \\
\text { IVR }\end{array}$ \\
\hline Conservatism & + & - & - & ++ & + & - \\
\hline Uniformity & + & -- & $?$ & ++ & + & - \\
\hline Professionalism & - & ++ & $?$ & -- & - & + \\
\hline Secrecy & ++ & -- & - & ++ & + & - \\
\hline
\end{tabular}

In addition to supporting the expansion of Hofstede-Gray relationships to include Hofstede's fifth and sixth cultural dimensions, Borker also proposes a favorable cultural profile based on Gray accounting values for the establishment of IFRS-based accounting systems and on an examination of Hofstede value indices for the United States, the United Kingdom, Australia, Canada, and New Zealand (Borker, 2013b). This IFRS-favorable profile is summarized in Table 9.

Table 9: IFRS Favorable Accounting Value Profile based on Gray's Accounting Value Dimensions (Borker, 2013b)

\begin{tabular}{|c|c|}
\hline Hypotheses/Gray Accounting Dimensions & IFRS Favorable Profile \\
\hline H1 Professionalism vs. Statutory Control & Professionalism \\
\hline H2 Uniformity versus Flexibility & Flexibility \\
\hline H3 Conservatism versus Optimism & Optimism \\
\hline H4 Secrecy versus Transparency & Transparency \\
\hline
\end{tabular}

This IFRS favorable profile is used as a point of reference and comparison in analyzing results from the $3 \mathrm{G}$ countries. 


\section{RESULTS FOR THE 3G ECONOMIES}

\section{Results and Analysis of the 3Gs: Hofstede Cultural Dimensions}

The Hofstede cultural dimension scores of the 3Gs are presented in Table 10. Definitions and discussion of the dimensions of the 3Gs in the section that follows are taken directly from Hofstede (2001; Hofstede, Hofstede, \& Minkov, 2010). All of the dimension values were obtained for all of the $3 \mathrm{G}$ countries with one exception. No Long-Term Orientation (LTO) value was available for Mongolia. It should further be noted that dimension values for Mongolia are based on published research that has not been recognized by Hofstede and his research associates and that the Mongolian survey respondents were between the ages of 17 and 24 (Tkaczuk, et al., 2010). Analytical statements comparing the $3 \mathrm{Gs}$ within each dimension are those of the author.

Table 10: Results of Hofstede Six Cultural Dimensions by 3G Country (Borker, 2013a)

\begin{tabular}{|c|c|c|c|c|c|c|c|c|c|c|c|}
\hline 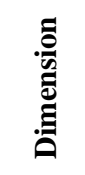 & 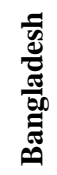 & تี & $\underset{\overrightarrow{0}}{\overrightarrow{0}}$ & 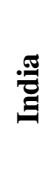 & 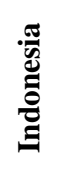 & $\underset{F}{\mathbb{E}}$ & 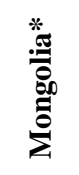 & & 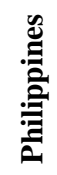 & 㞼 & 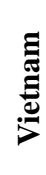 \\
\hline PDI & 80 & 80 & 70 & 77 & 78 & 95 & 7 & 80 & 94 & 80 & 70 \\
\hline IDV & 20 & 20 & 25 & 48 & 14 & 30 & 36 & 30 & 32 & 35 & 20 \\
\hline MAS & 55 & 66 & 45 & 56 & 46 & 70 & 6 & 60 & 64 & 10 & 40 \\
\hline UAI & 60 & 40 & 80 & 40 & 48 & 85 & 50 & 55 & 44 & 45 & 30 \\
\hline LTO & 40 & 118 & 7 & 61 & 62 & 30 & 28 & 16 & 19 & 45 & 80 \\
\hline IVR & 20 & 24 & 4 & 26 & 38 & 17 & N/A & 84 & 42 & 64 & 35 \\
\hline
\end{tabular}

Using the data in Table 10, values for the six Hofstede cultural dimensions are summarized graphically for each of the $3 \mathrm{Gs}$ in Figure 1.

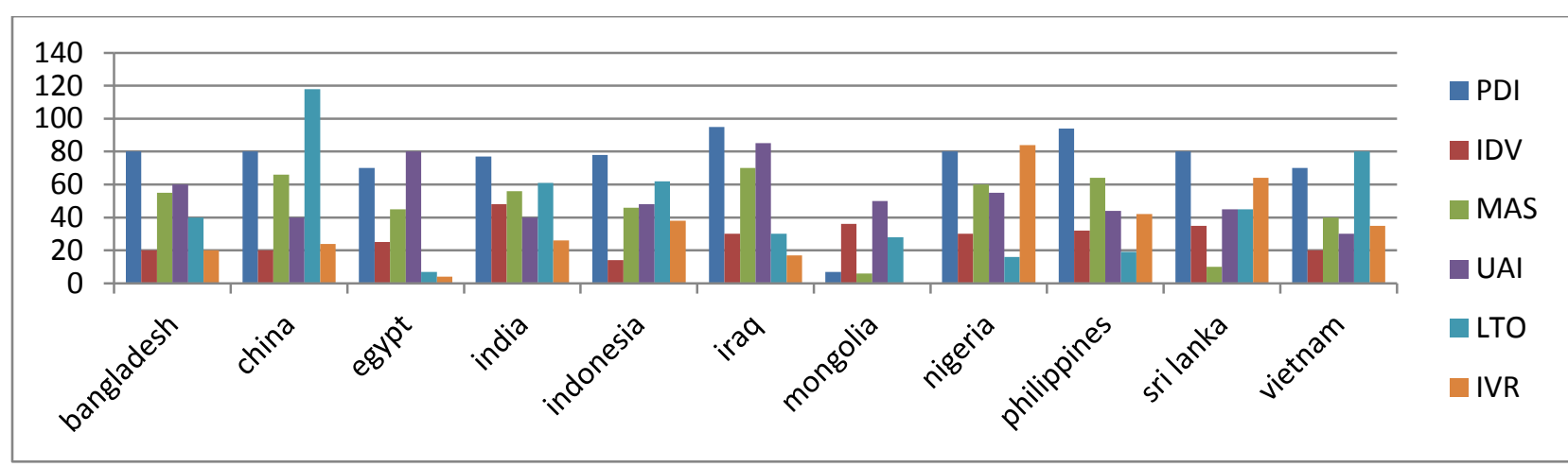

Figure 1: Graph of Hofstede Six Cultural Dimension by Individual 3G (Borker, 2013a)

\section{Results and Analysis of the 3Gs: Gray Accounting Value Dimensions}

In this section, we attribute four accounting value dimensions developed by Gray to each of the $3 \mathrm{Gs}$ based on Gray's hypothesized relationships between his own accounting dimensions and Hofstede's cultural values. This analysis considers both the relative position of the eleven $3 \mathrm{Gs}$ sample to one another and takes into consideration the larger population of all countries for which Hofstede has established scores for his first four dimensions. The expanded matrix of relationships between Gray and Hofstede dimensions (Table 8) is utilized and the greater importance of certain Hofstede dimensions over others, indicated by a double plus or double minus sign in the section, is given greater weight in the analysis. Based on this examination, the following attributions of Gray accounting values are proposed for the $3 \mathrm{Gs}$ in Table 11 . Results are indicated by the name of the accounting value and are modified upward or downward by one or more pluses or minuses. In cases where the result is midway between the two value polarities of the dimension, both values are indicated separated by a slash, with the order determined by which of the two appears to be slightly stronger. 
Table 11: Results of Gray Accounting Values for Each 3G Countries based on Gray Four Dimensions

\begin{tabular}{|l|l|l|l|l|}
\hline $\begin{array}{c}\text { 3G } \\
\text { Economies }\end{array}$ & $\begin{array}{c}\text { Professionalism versus } \\
\text { Statutory Control }\end{array}$ & $\begin{array}{c}\text { Uniformity versus } \\
\text { Flexibility }\end{array}$ & $\begin{array}{c}\text { Conservatism versus } \\
\text { Optimism }\end{array}$ & $\begin{array}{c}\text { Secrecy versus } \\
\text { Transparency }\end{array}$ \\
\hline Bangladesh & Statutory Control & Uniformity & Conservatism & Secrecy \\
\hline China & $\begin{array}{l}\text { Professionalism/Statutory } \\
\text { Control }\end{array}$ & Uniformity(-) & Conservatism/Optimism & Secrecy (-) \\
\hline Egypt & Statutory Control & Uniformity & Conservatism & Secrecy \\
\hline India & Professionalism & Flexibility/Uniformity & Optimism/Conservatism & Transparency/Secrecy \\
\hline Indonesia & Statutory Control & Uniformity & Conservatism & Transparency \\
\hline Iraq & Statutory Control & Uniformity & Conservatism & Transparency \\
\hline Mongolia & Statutory Control & Flexibility & Optimism/Conservatism & Transparency \\
\hline Nigeria & Statutory Control (-) & Uniformity & Conservatism (-) & Secrecy \\
\hline Philippines & Professionalism & Uniformity (-) & Conservatism/Optimism & Secrecy \\
\hline Sri Lanka & Professionalism & Uniformity (-) & Conservatism & Secrecy \\
\hline Viet Nam & Professionalism (-) & Uniformity (-) & Conservatism/Optimism & Secrecy \\
\hline
\end{tabular}

Analysis of Gray Results for the 3G Countries

A common Gray dimension among the 3Gs is that of uniformity as opposed to flexibility. Nine of the eleven countries exhibit some degree of uniformity. The exceptions are India and Mongolia, which in Section V are ranked first and second, respectively, with regard to closeness of their overall Gray value profile to the IFRS profile illustrated in Table 7. As has already been noted, the Hofstede dimensions for Mongolia, from which its Gray value dimension have been derived, were based on a recent survey of a very young sample that may well be less representative of the broader population. Uniformity reflects a strong tendency toward a high level of enforcement of standardized and consistent accounting practices as opposed to flexibility which permits some creativity in finding appropriate accounting solutions to changes in the business activities and reporting needs.

Another common dimension in the group was conservatism as opposed to optimism. Nine of the eleven 3Gs exhibited at least some degree of conservatism, with the exception, again, being India and Mongolia. Conservatism tends to be a vigilant approach to accounting measurement, as opposed to a more optimistic and risktaking approach, which might permit fair value and other innovative notions.

On the dimension of secrecy versus transparency, seven of the eleven countries exhibited a degree of secrecy. Secrecy reflects a tendency toward confidentiality and the constraint of disclosure of information, as opposed to a more transparent and publicly accountable approach. It is more pervasive in societies lacking a tradition of having individual equity investors dependent upon public information for investing decisions and open equity markets.

Finally, on the professionalism versus statutory control dimension, six out of the eleven 3Gs exhibited a degree of statutory control. This is associated with strict government rules for accounting determined by decree or legislation, leaving little room for professional accounting decisions. On the other hand, five of the countries exhibited some degree of professionalism, a value that favors professional standard-setting and professional selfregulation.

\section{Ranking of Gray Results Based on Closeness to IFRS Profile}

It is helpful to reorder the Gray dimension profile information for the $3 \mathrm{Gs}$ provided in Table 11 to provide a ranking of the 3Gs from closest to most remote from the proposed IFRS profile, as shown in Table 7. This is seen in Table 12, which, for comparative purposes, juxtaposes the IFRS accounting profile to the Gray accounting value profile derived for each of the $3 \mathrm{Gs}$. Also provided for comparison is a column providing the $3 \mathrm{G}$ Index ranking of each $3 \mathrm{G}$. 
Table 12: 3Gs Listed from Closest to Most Remote from IFRS Favorable Profile by Rank

\begin{tabular}{|c|c|c|c|c|c|c|}
\hline $\begin{array}{l}\text { IFRS } \\
\text { Rank }\end{array}$ & $\begin{array}{c}\mathbf{3 G} \\
\text { Rank }\end{array}$ & 3G Economy/ & \multicolumn{2}{|c|}{ Individual Country Profile } & \multicolumn{2}{|c|}{ IFRS Favorable Profile } \\
\hline 1 & 3 & India & $\begin{array}{l}\text { Professionalism } \\
\text { Optimism/Conservatism }\end{array}$ & $\begin{array}{l}\text { Flexibility/Uniformity } \\
\text { Transparency/Secrecy }\end{array}$ & $\begin{array}{l}\text { Professionalism } \\
\text { Optimism }\end{array}$ & $\begin{array}{l}\text { Flexibility } \\
\text { Transparency }\end{array}$ \\
\hline 2 & 5 & Mongolia & $\begin{array}{l}\text { Statutory Control } \\
\text { Optimism/Conservatism }\end{array}$ & $\begin{array}{l}\text { Flexibility } \\
\text { Transparency }\end{array}$ & $\begin{array}{l}\text { Professionalism } \\
\text { Optimism }\end{array}$ & $\begin{array}{l}\text { Flexibility } \\
\text { Transparency }\end{array}$ \\
\hline 3 & 6 & Philippines & $\begin{array}{l}\text { Professionalism } \\
\text { Conservatism/Optimism }\end{array}$ & $\begin{array}{l}\text { Uniformity (-) } \\
\text { Secrecy }\end{array}$ & $\begin{array}{l}\text { Professionalism } \\
\text { Optimism }\end{array}$ & $\begin{array}{l}\text { Flexibility } \\
\text { Transparency }\end{array}$ \\
\hline 3 & 1 & Viet Nam & $\begin{array}{l}\text { Professionalism (-) } \\
\text { Conservatism/Optimism }\end{array}$ & $\begin{array}{l}\text { Uniformity (-) } \\
\text { Secrecy }\end{array}$ & $\begin{array}{l}\text { Professionalism } \\
\text { Optimism }\end{array}$ & $\begin{array}{l}\text { Flexibility } \\
\text { Transparency }\end{array}$ \\
\hline 4 & 2 & China & $\begin{array}{l}\text { Professionalism/Statutory } \\
\text { Control } \\
\text { Optimism/Conservatism }\end{array}$ & $\begin{array}{l}\text { Uniformity (-) } \\
\text { Secrecy (-) }\end{array}$ & $\begin{array}{l}\text { Professionalism } \\
\text { Optimism }\end{array}$ & $\begin{array}{l}\text { Flexibility } \\
\text { Transparency }\end{array}$ \\
\hline 5 & 10 & Sri Lanka & $\begin{array}{l}\text { Professionalism } \\
\text { Conservatism/Optimism }\end{array}$ & $\begin{array}{l}\text { Uniformity (-) } \\
\text { Secrecy }\end{array}$ & $\begin{array}{l}\text { Professionalism } \\
\text { Optimism }\end{array}$ & $\begin{array}{l}\text { Flexibility } \\
\text { Transparency }\end{array}$ \\
\hline 6 & 4 & Indonesia & $\begin{array}{l}\text { Statutory Control } \\
\text { Conservatism }\end{array}$ & $\begin{array}{l}\text { Uniformity } \\
\text { Transparency }\end{array}$ & $\begin{array}{l}\text { Professionalism } \\
\text { Optimism }\end{array}$ & $\begin{array}{l}\text { Flexibility } \\
\text { Transparency }\end{array}$ \\
\hline 6 & 7 & Iraq & $\begin{array}{l}\text { Statutory Control } \\
\text { Conservatism }\end{array}$ & $\begin{array}{l}\text { Uniformity } \\
\text { Transparency }\end{array}$ & $\begin{array}{l}\text { Professionalism } \\
\text { Optimism }\end{array}$ & $\begin{array}{l}\text { Flexibility } \\
\text { Transparency }\end{array}$ \\
\hline 7 & 11 & Nigeria & $\begin{array}{l}\text { Statutory Control (-) } \\
\text { Conservatism/Optimism }\end{array}$ & $\begin{array}{l}\text { Uniformity } \\
\text { Secrecy }\end{array}$ & $\begin{array}{l}\text { Professionalism } \\
\text { Optimism }\end{array}$ & $\begin{array}{l}\text { Flexibility } \\
\text { Transparency }\end{array}$ \\
\hline 8 & 8 & Bangladesh & $\begin{array}{l}\text { Statutory Control } \\
\text { Conservatism }\end{array}$ & $\begin{array}{l}\text { Uniformity } \\
\text { Secrecy }\end{array}$ & $\begin{array}{l}\text { Professionalism } \\
\text { Optimism }\end{array}$ & $\begin{array}{l}\text { Flexibility } \\
\text { Transparency }\end{array}$ \\
\hline 8 & 9 & Egypt & $\begin{array}{l}\text { Statutory Control } \\
\text { Conservatism }\end{array}$ & $\begin{array}{l}\text { Uniformity } \\
\text { Secrecy }\end{array}$ & $\begin{array}{l}\text { Professionalism } \\
\text { Optimism }\end{array}$ & $\begin{array}{l}\text { Flexibility } \\
\text { Transparency }\end{array}$ \\
\hline
\end{tabular}

It should be noted that all but one of the top five performers on the $3 \mathrm{G}$ Index is within the top four rankings for IFRS cultural attributes. At the same time, all of the five lowest performers on the $3 \mathrm{G}$ Index have IFRS rankings at the low end of the range; i.e., rankings of 5-8. Figure 2 reflects a scatter graph and linear trend line of the data with IFRS rank on the $y$-axis and $3 G$ Index rank on the $x$-axis showing that there is a positive correlation between the two rankings. The correlation is a positive 0.67 and an R-squared of 0.44 .

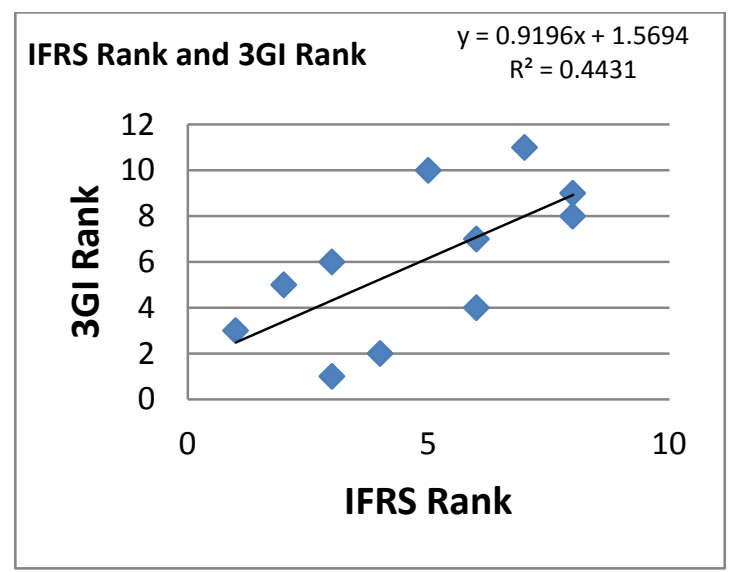

Figure 2: Scatter Graph Of IFRS And 3G Index Rankings With Linear Regression Trend Line

Linear regression of the data indicates that there is a positive relationship between IFRS and $3 \mathrm{G}$ Index rankings. However, given the resultant R-squared, there are other factors involved for each beyond this relationship.

For purposes of comparison with the profiles in Table 12, a summary of Gray-based accounting value profiles for the United States and Russia is provided in Table 13. 
Table 13: Profiles for United States and Russia Compared with IFRS Favorable Profile

\begin{tabular}{|l|ll|ll|}
\hline 3G Country/ & \multicolumn{2}{|c|}{ Individual Country Profile } & \multicolumn{2}{c|}{ IFRS Favorable Profile } \\
\hline United States & Professionalism & Flexibility & Professionalism & Flexibility \\
& Optimism & Transparency & Optimism & Transparency \\
\hline Russia & Statutory control & Uniformity & Professionalism & Flexibility \\
& Conservatism & Secrecy & Optimism & Transparency \\
\hline
\end{tabular}

The accounting value profiles of the United States and Russia are completely opposite from one another, with the profile of the former being identical with the IFRS-favorable profile and that of the latter being the complete opposite. The profiles for the $3 \mathrm{Gs}$ include examples of Russia's profile and intermediate combinations of values. India's profile comes closest to that of the United States and the IFRS-favorable profile, with some degree of greater proximity to the IFRS profile on all four of the Gray accounting values.

\section{DISCUSSION}

\section{Gray Dimensions and the $3 G$ countries}

The profiles of Gray accounting value dimensions derived for the 3Gs suggest certain groupings of countries based on similar profiles of relative closeness/remoteness to the IFRS Profile. Specifically, three groups are identified, that together comprise nine of the eleven 3Gs. The groups are (1) Most Remote, (2) Remote except for Transparency, and (3) Less Remote with Professionalism. These groups are illustrated in Table 14. Dimensions opposite to the IFRS profile are shaded.

Table 14: 3G Country Grouping Based on Similarity of Accounting Value Profiles

\begin{tabular}{|l|l|l|l|l|l|}
\hline 3G Index & Group 1 & \multicolumn{5}{|c|}{ Most Remote from IFRS } \\
\hline 0.39 & Bangladesh & Statutory Control & Uniformity & Conservatism & Secrecy \\
\hline 0.37 & Egypt & Statutory Control & Uniformity & Conservatism & Secrecy \\
\hline 0.25 & Nigeria & Statutory Control (-) & Uniformity & Conservatism (-) & Secrecy \\
\hline
\end{tabular}

\begin{tabular}{|l|l|l|l|l|l|}
\hline 3G Index & \multicolumn{1}{|c|}{ Group 2 } & \multicolumn{4}{|c|}{ Remote from IFRS but Exhibiting Transparency } \\
\hline 0.70 & Indonesia & Statutory Control & Uniformity & Conservatism & Transparency \\
\hline 0.58 & Iraq & Statutory Control & Uniformity & Conservatism & Transparency \\
\hline
\end{tabular}

\begin{tabular}{|l|l|l|l|l|l|}
\hline 3G Index & \multicolumn{1}{|c|}{ Group 3 } & \multicolumn{4}{|c|}{ Less Remote from IFRS and Exhibiting Professionalism } \\
\hline 0.63 & Philippines & Professionalism & Uniformity (-) & $\begin{array}{l}\text { Conservatism/ } \\
\text { Optimism }\end{array}$ & Secrecy \\
\hline 0.33 & Sri Lanka & Professionalism & Uniformity (-) & Conservatism & Secrecy \\
\hline 0.86 & Viet Nam & Professionalism (-) & Uniformity (-) & $\begin{array}{l}\text { Conservatism/ } \\
\text { Optimism }\end{array}$ & Secrecy \\
\hline 0.81 & China & $\begin{array}{l}\text { Professionalism/ } \\
\text { Statutory Control }\end{array}$ & Uniformity(-) & $\begin{array}{l}\text { Conservatism/ } \\
\text { Optimism }\end{array}$ & Secrecy (-) \\
\hline
\end{tabular}

India is closest to the IFRS Profile of the eleven $3 \mathrm{G}$ countries, with positions on each of the Gray accounting dimensions to some degree closer to IFRS. Mongolia is next closest to the IFRS Profile in that it has, to some degree, three out of four positions closer to IFRS, which is illustrated in Table 15.

Table 15: India and Mongolia

\begin{tabular}{|l|l|l|l|l|}
\hline India 0.71 & Professionalism & Flexibility/Uniformity & Optimism/Conservatism & Transparency/Secrecy \\
\hline Mongolia 0.63 & Statutory Control & Flexibility & Optimism/Conservatism & Transparency \\
\hline
\end{tabular}

India exhibits the closest culturally-based accounting values to IFRS. Mongolia exhibits the next closest characteristics, yet the narrow and very young age group and different timing of the Mongolia survey using Hofstede's standard questionnaire raises doubts about whether these results are truly representative of the Mongolian business population. If an older or mixed survey sample had been used, one might have expected results similar to former Soviet Central Asian republics like Kazakhstan or Uzbekistan, which, when translated into Gray accounting value dimensions, look the same as the profile for Russia and opposite to the IFRS profile. 
Generally, there appears to be a positive association between high ranking for closeness to IFRS and a high 3G Index. This would suggest that an accounting cultural orientation to IFRS may be a positive factor for economic growth potential.

To review and evaluate the results of the analysis above, it is necessary to return to the basic intension of Gray's four hypotheses and his accounting value dimensions. These dimensions are not intended to identify positive versus negative influences on accounting. Rather, Gray's dimensions characterize different contrasting aspects of accounting values that can affect the development of accounting systems in different directions. Each value can be seen as reflecting both advantages and disadvantages associated with systems of accounting. Conservatism is acknowledged as an old and venerated accounting value associated with care, caution, and prudence. At the same time, it leaves little room for creativity or new ways of solving reporting problems. Nevertheless, as noted above, a specific combination of Gray attributes, identified with the Anglo-Saxon Accounting countries, can be identified as the favorable IFRS profile presented here. They characterize cultures which, disregarding external influences and other special internal factors, would tend to develop accounting systems oriented toward IFRS accounting values.

\section{Significance of Variances to IFRS Profile on IFRS Implementation}

Five of the $3 \mathrm{G}$ sample have been identified as having implicit culturally-based accounting values that are remote or fairly remote from the IFRS profile. This does not mean that Bangladesh, Egypt and Nigeria are less likely to be successful in their long-term implementation of IFRS. For that matter, India, which ranked highest for closeness of accounting values to IFRS, has had to overcome many obstacles and delays in implementing IFRS and is about a year past its planned implementation. The brief review of the status of the various 3Gs with regard to IFRS adoption in Table 3 attests to the fact that there is not a sure connection between cultural readiness and timely success. Nonetheless, countries with cultural accounting values more remote from the IFRS value profile may have more to overcome in adopting and continuing to evolve with IFRS since, by their nature, IFRS tend to evolve and adapt to changes in the nature of business transactions over time. In addition to the issues that any nation encounters in the complex process of IFRS adoption, most of the $3 \mathrm{G}$ countries have, to a greater or lesser extent, specific cultural challenges to overcome.

Countries with cultural accounting values that are more remote from IFRS could find it useful to utilize a variety of ameliorating strategies to adopt and maintain accounting values supportive of IFRS (Borker, 2012a). These include (a) establishing culturally sensitive education and professional training programs, (b) introducing culturally-focused upgrade programs for existing accounting professionals, (c) empowering national accounting standard-setting bodies to integrate the values of professionalism, flexibility, optimism, and transparency into their professional activities, (d) setting realistic timeframes and deadlines for the transition to IFRS to allow the local accounting culture to catch up with new IFRS reforms, (e) establishing a comprehensive change management program for accounting professionals, businesses, government, and the public with necessary change management tools to make a successful transition, and (f) creating robust support infrastructures for IFRS implementation (Borker, 2012a) (Borker, 2012b).

\section{Other Factors Affecting Success of IFRS Implementation}

A review of the history and current status of IFRS implementation, provided in Table 2, makes it clear that other factors, besides cultural accounting values, play an important role in the success of IFRS implementation. Iraq, for example, is fully compliant with IFRS for all listed companies, while India, with the highest ranking on a cultural accounting value basis, has suffered a series of delays resulting from wrangling among its political parties. The success of Iraq, at least in the short term, reflects the impact of an outside government - the United States which has been heavily involved in Iraq's market and reporting development. In the case of India, its democratic diversity has resulted in delays, yet its basic cultural values may assure success of IFRS reporting in the long term. Clearly, economic incentives and political forces play a major role in the adoption of IFRS by national governments and individual companies. 


\section{Significance of Long-term IFRS Success for Achieving 3Gs' Economic Growth Projections}

The establishment of long-term stability and IFRS in the $3 \mathrm{Gs}$ is critical to meeting their economic growth targets. High quality world recognized reporting standards can only insure that each $3 \mathrm{G}$ receives its fair allocation from the global capital markets. IFRS will also have a profound impact on several of the growth factors used by Buiter and Rahbari to evaluate each country's growth potential. IFRS will increase stability, stewardship, accountability and transparency at both the company and government institutional level. It will increase the general level of professional education of accountants and accounting standards-setting bodies and improve their policies and decision-making. It will encourage the involvement of individual citizens participating as investors in the domestic capital markets, which will have a positive impact on the general education and contribute to the democratization of the society. Successfully establishing a general atmosphere of accountability and transparency could have a profound effect on decreasing the level of corruption in these countries at the personal, company and government level. To the extent that successful adoption of IFRS can contribute in any real way to the reduction of corruption, it will have reduced the burden of one of the major impediments to economic growth and improvement of life in the developing world.

\section{CONCLUSION}

The study indicates that the 3Gs with accounting value profiles close to the IFRS favorable profile tend to be ranked higher on the $3 \mathrm{G}$ Index than countries with profiles more remote from the IFRS profile. However, certain limitations on the study need to be acknowledged. In the case of Mongolia, the Hofstede data, on which our Gray accounting value profiling is based, can be questioned due to the narrow, rather young age range of the survey sample. As already mentioned, one may well question whether such a sample can be considered representative of the adult population as a whole and, particularly, those in power positions in management and government. At the same time, it is possible that the data on Mongolia is a legitimate reflection of a significant shift in cultural values caused by the influx of heavy direct investment and cultural influence of Western developed countries by direct presence and the Internet. Hofstede's assumption is that his cultural values are long-standing and only shift over longer time periods; i.e., centuries. However, history tells us that societies can stay stable for long periods of time and suddenly change in some way due to a significant external event or influence. This discussion raises the broader issue of how frequently value surveys, like Hofstede's, need to be updated in order to reliably reflect the current cultural value profiles of all countries relative to one another. This is an important idea to consider since it may be assumed that much of Hofstede's world-wide survey data originates from the time of his first book in 1980.

With regard to this $3 \mathrm{G}$ study, further work would help to place what we have determined so far in a broader perspective. It would be valuable to apply our analysis to those countries that Buiter and Rahbari considered but did not choose to include in the $3 \mathrm{G}$ group, although they received an "honorable mention." These countries include Iran and North Korea, once they handle their current political issues, and Mexico, Brazil, Turkey, and Thailand. More broadly, it would be useful to analyze all of the developing and transitional countries to see how their cultural and accounting value profiles compare with those of the 3Gs. A broader study of all developing and transitional countries could shed greater light on the cultural and accounting values that support strong and sustained economic growth.

Successful and sustaining IFRS implementation in the 3Gs is an important factor for meeting their longterm growth projections. The use of Gray accounting value dimensions provides a useful basis for developing implicit accounting value profiles for each $3 \mathrm{G}$ that can help to anticipate challenges that may need to be overcome through education and professional training and other measures suggested in Section V. The fact that the accounting value profiles were found to complement the $3 \mathrm{G}$ Index results based on economic growth criteria further supports the value of this approach.

\section{AUTHOR INFORMATION}

David Borker has a PhD from Yale with a Master of Accounting/MBA from Ohio State University and an A.B. from Cornell. Dr. Borker has extensive experience as an academic consultant and a businessman working in Europe and Central Asia. He teaches accounting and management at Manhattanville College and is a licensed CPA. E-mail: David.Borker@mville.edu 


\section{REFERENCES}

1. $\quad$ ASEAN Federation of Accountants, 2009. ASEAN Accountancy News, s.1.: s.n.

2. Ball, R., 2008. What is the Actual Economic Role of Financial Reporting?. Accounting Horizons, 22(4), pp. 427-432.

3. $\quad$ Bangladesh, T. I. o. C. A. o., n.d. $\neg$ The Institute of Chartered Accountants of Bangladesh, s.l.: s.n.

4. Baskerville, R., 2003. Hofstede Never Studied Culture. Accounting, Organizations and Society, 28(1), pp. $1-14$.

5. $\quad$ Baydoun, N. \& Willet, R., 1995. Cultural Relevance of Western Accounting Systems to Developing Countries. ABACUS, 31(1), pp. 67-92.

6. Borker, D. R., 2012a. Accounting, Culture And Emerging Economies: IFRS In The BRIC Countries. Journal of Business and Economics Research, Volume 5, pp. 313-324.

7. Borker, D. R., 2012a. Stepped-Up Progress On IFRS In Russia: History In The Making. International Business \& Economics Research Journal, 11(2), pp. 255-268.

8. Borker, D. R., 2012b. Accounting, Culture and Emerging Economies: IFRS in Central and Eastern Europe. International Business \& Economics Research Journal, 11(9), pp. 1003-1017.

9. Borker, D. R., 2013a. Economic Drivers and Cultural Values: The 3G Countries. The Business Review, Cambridge, 20(2).

10. Borker, D. R., 2013b. Is There a Favorable Cultural Profile for IFRS?: An Examination and Extension of Gray's Accounting Value Hypotheses. International Business \& Economics Research Journal, 12(2), pp. 167-177.

11. Buiter, W. \& Rahbari, E., 2011. Global Growth Generators: Moving beyond 'Emerging Markets' and 'BRIC', Chicago: Citigroup Global Markets.

12. Buys, P. W. \& Schutte, D., 2011. A Consideration Of IFRS Education. International Business \& Economics Research Journal, 10(12), pp. 49-58.

13. Chanchani, S. \& MacGregor, S., 1999. A Synthesis of Cultural Studies in Accounting. Journal of Accounting, Volume 18, pp. 1-30.

14. Chanchani, S. \& Willet, R., 2004. An Empirical Assessment of Gray's Accounting Value Constructs. International Journal of Accounting, 39(2), pp. 125-154.

15. Deloitte, 2008. Financial Reporting Framework in Iraq, s.1.: s.n.

16. Deloitte, 2012. IFRSs in your pocket, s.l.: s.n.

17. Doupnik, T. \& Tsakumis, G., 2004. A Critical Review of Tests of Gray's Theory of Cultural Relevance and Suggestions for Future Research. Journal of Accounting Literature, Volume 23, pp. 1-48.

18. Elbannan, M., 2010. Accounting and stock market effects of international accounting standards adoption in an emerging economy. Review of Quantitative Finance \& Accounting, pp. 207-245.

19. Emenyonu, E. \& Gray, S. J., 1992. EC Accounting Harmonisation: An Empirical Study of Measurement Practices in France, Germany and the UK. Accounting and Business Research, 23(89), p. 49.

20. $\quad$ eStandardsForum, 2008. Best Practice Report - Sri Lanka, s.1.: s.n.

21. Farag, S., 2009. The Accounting Profession in Egypt: Its Origin and Development. The International Journal of Accounting, 44(2), pp. 403-414.

22. Financial Standards Foundation, 2008. BestPractice Report - China, s.l.: s.n.

23. Finch, N., 2009. Towards an Understanding of Cultural Influence on the International Practice of Accounting. Journal of International Business and Cultural Studies.

24. Gray, S. J., 1988. Towards a Theory of Cultural Influence on the Development of Accounting Systems Internationally. Abacus, 24(1), pp. 9-11, 12.

25. Gray, S. \& Vint, H., 1995. The Impact of Culture on Accounting Disclosures: Some International Evidence. Asia-Pacific Journal of Accounting, Volume 21, pp. 33-43.

26. Hodstede, G. \& Bond, M., 1988. The Confucius Connection: From Cultural Foots to Economic Growth. Organisational Dynamics, 16(1), pp. 5-21.

27. Hofstede, G., 1980. Cultures Consequences: International Differences in Work Related Values. Newbury Park, NJ: Sage.

28. Hofstede, G., 1994. The Pitfalls of Cross-National Survey Research: A Reply to the Article by Spector et al. on the Psychometric Properties of the Hofstede Values Survey Module 1994. Applied Psychology, 51(1), pp. 170-173. 
29. Hofstede, G., 2001. Culture's Consequeces: Comparing Values, Behaviors, Institutions, and Organizations across Nations. 2 ed. ed. Thousand Oaks, London, New Delhi: Sage Publications.

30. Hofstede, G., Hofstede, G. J. \& Minkov, M., 2010. Cultures and Organizations: Software of the Mind: Intercultural Cooperation and its Importance for Survival. New York: McGrawHill.

31. Hope, O.-K., 2003. Firm-level Disclosures and the Relative Roles of Culture and Legal Origin.. Journal of International Financial Management and Accounting, Volume 14, pp. 218-248.

32. Huang, Y., 2007. Relationships Between National Cultures and Hofstede Model , and Implications for a Multinational Enterprise. 13th Asia Pacific Management Conference (2007), pp. 1422-1428.

33. Idonesian Accounting Board, 2011. 2012 IFRS Convergence Progress in Indonesia., s.1.: s.n.

34. Khatri, J., 2011. The Economic Times, s.1.: s.n.

35. Khatri, J. \& Master, A., 2009. Convergence with International Reporting Standards ('IFRS') -- Impact on Fundamental Accounting Practices and Reulatory Framework of India. Bombay Chartered Accountant Journal, pp. 71-74.

36. Kholeif, A., 2008. A New Institutional Analysis of Ifrs Adoption in Egypt: A Case Study of Loosely Coupled Rules and routines. School of Accounting, Finance and Management, University of Essex, Essex, $U K$..

37. Lima, V. S. d. et al., 2010. Toward IFRS: Economic Consequences of Accounting Convergence in an Emerging Economy. Research in Emerging Economies, Volume 10, pp. 251-295.

38. McGregor, R., 2006. China Adopts New Accounting Standards. Financial Times Website.

39. Mir, M. \& Rahaman, A., 2005. The adoption of international accounting standards in Bangladesh. Emerald Journal Article, 18(6), pp. 816-841.

40. O'Neill, J., 2001. Building Better Global Economic BRICs, New York: Goldman Sachs.

41. Perera, H., 1989. Towards a framework to analyze the impact of culture on accounting. The International Journal of Accounting, Volume 24, pp. 42-56.

42. PWC, 2012. IFRS Adoption by Country, s.1.: s.n.

43. ROSC, 2008. Mongolia - Accounting and Auditing, s.1.: s.n.

44. Salter, S. \& Niswander, F., 1995. Cultural Influence on the Development of Accounting Systems Internationally: A Test of Gray's [1988] Theory. Journal of International Business Studies, 26(2), pp. 379397.

45. Sarikas, R. H., Hien, V. D. \& Djatej, A. M., 2009. International Influence on Accountancy in Vietnam. In: Corporate Governance in Developing Economies. s.l.:s.n.

46. Shil, N. C. D. B. \&. P. A. K., 2009. Harmonization of Accounting Standards through Internationalization. International Business Research, 2(2).

47. Shil, N., Das, B. \& Pramanik, A., 2009. Harmonization of Accounting Standards through Internationalization. International Business Research, Vol. 2, No. 2., 2(2).

48. Sondergaard, M., 1994. Hofstede's consequences: A study of reviews, citations and replications. Organization Studies, 15(3), pp. 447-456.

49. Spector, P. E., 2001. Relationships Between National Cultures and Hofstede Model , and Implications For A Multinational Enterprise. Applied Psychology" An International Review, 50(2), pp. 269-281.

50. Terzungwe, N., 2012. Expected Benefits of Implementing Global Accounting Standards by Nigerian business Entities. International Journal of Business and Management, 7(15), pp. 98-104.

51. The Accountant, 2010. Philippines adopt IFRS for SMEs, s.1.: International Accounting Bulletin.

52. The Indonesia Institute of Accountants, 2009. Konvergensi Standar Akuntansi Keuangan (SAK) Indonesiake International Financial Reporting Standards (IFRS), s.l.: s.n.

53. The Institute of Chartered Accountants of Bangladesh, 2007. Current Status of Bangladesh Accounting Standards( BASs ) vis-à-vis IASs/IFRSs, s.l.: s.n.

54. The Institute of Chartered Accountants of Bangladesh, 2009. Actions Plans, s.1.: s.n.

55. The Institute of Chartered Accountants of India, 2010. 61st Annual Report and Audited Annual Accounts of the Institute for the Year 2009 - 2010, s.1.: s.n.

56. The Institute of Chartered Accountants of India, 2011. 62nd Annual Report and Audited annual accounts of the institute for the year 2010 - 2011, s.1.: s.n.

57. The Institute of Chartered Accountants of Nigeria, 2009. Action Plan Developed by The Institute of Chartered Accountants of Nigeria (ICAN), s.1.: s.n. 
58. Tkaczuk, A., Badarch, Z. \& Tureckov, I., 2010. Cultural Dimensions Analysis: Russia, Mongolia, Poland Example, Warsaw: Warsaw University of Life Science.

59. Tomor-Ochir, S., 2010. Accounting Law of Mongolia, s.1.: s.n.

60. U.S. Department of State, 2008. 2008 Investment Climate Statement - Sri Lanka, s.1.: s.n.

61. UNCTAD Secretariat, 2008. Review of Practical Implementation Issues Relating to International financial Reporting Standards, s.l.: s.n.

62. UNCTAD, 2006. International Accounting and Reporting Issues: 2005 Review, s.1.: United Nations.

63. Venus, I. \& Sales-Suez, M., 2011. A comparison of the International Financial Reporting Standards (IFRS) and Generally Accepted Accounting Principles (GAAP) for Small and Medium-sized Entities (SMES) and Compliances of Some Asian Countries to IFRS. Journal of International Business Research, 10(3).

64. World Bank Group, 2006. Reports on the Observance of Standards and Codes (ROSC) Republic of the Philippines, s.1.: s.n.

65. World Bank, 2002. Report on Observance of Standards and Codes (ROSC), s.1.: s.n.

66. World Bank, 2004. Sri Lanka: Report on the Observance of Standards and Codes - Accounting and Auditing, s.l.: s.n.

67. World Bank, 2005. Report on Observance of Standards and Codes (Republic of Indonesia). ROSC Accounting and Auditing, September.

68. World Bank, 2006. Corporate Governance country assessment Vietnam. Report on the Observance of Standards and Codes., s.1.: s.n.

69. World Bank, 2010. Report on the Observance of Standards and Codes (ROSC) Indonesia., s.1.: ROSC Accounting and Auditing.

70. World Bank, 2011. Report on the Observance of Standards and Codes (ROSC) Nigeria, s.1.: s.n.

71. Zarzeski, M. T., 1996. Spontaneous Harmonization Effects of Culture and Market Forces on Accounting Disclosure Practices. Accounting Horizons, Volume 10, pp. 18-37. 
NOTES 